\title{
Molecular Detection and Pathomorphological Studies of Canine Distemper Virus Infection (CDV) in Dogs
}

\author{
Mridusmrita Buragohain ${ }^{1 *}$, Sushanta Goswami ${ }^{1}$, Probodh Borah ${ }^{2}$, \\ Shameem Ara Begum ${ }^{1}$ and Bhaben Chandra Baishya ${ }^{3}$ \\ ${ }^{1}$ Department of Veterinary Pathology, College of Veterinary Science, Assam Agricultural University, Khanapara, \\ Guwahati, Assam, INDIA \\ ${ }^{2}$ Department of Animal Biotechnology, College of Veterinary Science, Assam Agricultural University, Khanapara, \\ Guwahati, Assam, INDIA \\ ${ }^{3}$ Department of Veterinary Medicine, College of Veterinary Science, Assam Agricultural University, Khanapara, \\ Guwahati, Assam, INDIA \\ *Corresponding author: M. Buragohain; E-mail: mridusmritaburagohain@gmail.com
}

Received: 25 Nov., 2020

Revised: 10 Jan., 2021

Accepted: 16 Jan., 2021

\begin{abstract}
In this study RT-PCR was used to detect CDV NP gene from the whole blood samples of dogs clinically suspected for CD followed by the study of pathomorphological alterations in different tissues. Clinical signs such as respiratory distress, purulent oculo-nasal discharge, biphasic fever, gastroenteritis, pustular dermatitis, prominent hyperkeratosis of the digital pads and nervous disorders were observed in the clinically suspected cases. The nervous disorder includes seizure, convulsion, paddling movement, tremor followed by posterior paralysis. On necropsy, bronchopneumonia, congestion and haemorrhages over the mucosal surface of the urinary bladder, stomach, intestine and brain were prominent lesions. Microscopically, both eosinophilic intranuclear and intracytoplasmic inclusion bodies were recorded in the neurons and glial cells, epithelial cells of the bronchioles, urinary bladder, kidney tubules and gastric glands. Congested vessels with haemorrhages were also found in the brain, lungs, stomach, intestine and lymphoid organs.

\section{HIGHLIGHTS}

(0 Amplification of NP gene was found in 41.67 percent $(n=25)$ cases out of total 60 sample tested by RT-PCR.

0 Most prominent clinical manifestations were oculo-nasal discharge, gastroenteritis, biphasic fever, hyperkeratosis, pustular dermatitis and nervous disorders.

( In histopathological studies inclusion bodies were recorded in the lungs, brain, kidneys, stomach and urinary bladder.
\end{abstract}

Keywords: Canine distemper virus, Dog, Histopathology, RT-PCR

Canine distemper (CD) is a potentially fatal, multisystemic and highly contagious viral disease of canines, which was recognized as one of the leading cause of high mortality in dogs (Dongre et al., 2013). Canine distemper is an infectious disease, infecting a broad range of animals including terrestrial and aquatic carnivores. The virus is shed primarily in the ocular and nasal secretions of the infected animals (Beineke et al., 2015).

Clinical diagnosis of CD is complicated due to its similar clinical signs with other respiratory and enteric disorders.
Molecular diagnosis gives confirmatory conclusion about the presence or absence of the viral antigen in the animals. Reverse transcriptase-polymerase chain reaction (RTPCR) is found to be one of the reliable techniques to detect

How to cite this article: Buragohain, M., Goswami, S., Borah, P. Begum, S.A. and Baishya, B.C. (2021). Molecular detection and pathomorphological studies of canine distemper virus infection (CDV) in dogs. J. Anim. Res., 11(1): 159-166.

Source of Support: None; Conflict of Interest: None 
canine distemper virus (CDV) antigen in the clinical samples (Kim et al., 2006; Yi and Cheng 2014), though its sensitivity varies with the nucleic acid extraction method and primers used for amplification of the target region (Saito et al., 2006). As the disease is contagious in nature and cause high mortality of young animals, therefore an early diagnosis of the disease is essential for proper treatment and to take care of the animals. The aim of the present study was to molecular detection of CDV at the early stage of the disease and correlate with pathomorphological alterations.

\section{MATERIALS AND METHODS}

\section{Collection of samples}

The sources of materials were Teaching Veterinary Clinical Complex (TVCC), College of Veterinary Science, Khanapara; State Veterinary Dispensary, Chenikuthi; Govt. of Assam and the other private clinics within the Guwahati city. Dogs with the history of fever, purulent oculo-nasal discharges, pneumonia, pustular dermatitis and neurological disorders were considered as suspected cases of CD for the present study. Samples were collected from a total of 60 clinically suspected cases. Three $\mathrm{ml}$ of blood was aseptically collected in EDTA vacutainer and stored at $-20^{\circ} \mathrm{C}$ for further analysis by RT-PCR.

\section{Histopathological examination}

Tissue samples from different organs showing specific lesions were collected in $10 \%$ formal saline solution at the ratio of 1:10 for histopathological examination. After proper fixation, tissue samples were processed for routine histopathological examination as per standard procedure (H\&E) (Culling, 1974).

\section{RT-PCR}

\section{Reverse transcription and amplification of NP gene}

Total RNA was extracted from $250 \mu$ l of whole blood samples via TRIzol ${ }^{\mathrm{TM}}$ (Thermo Scientific, Massachusetts, USA), following standard protocol. The cDNA was produced with Revert Aid TM M-MulV reverse transcriptase (Thermo Scientific). Reverse transcription was carried out at $70^{\circ} \mathrm{C}$ for $5 \mathrm{~min}$, followed by $25^{\circ} \mathrm{C}$ for $10 \mathrm{~min}$ and hold at $4^{\circ} \mathrm{C}$. Amplification of $\mathrm{CDV}$ nucleoprotein (NP) gene was obtained from the cDNA template with a NP gene specific primer pair (GenBank accession no.EF375619) along with the CDV vaccine (Nobivac DHPPi) as positive control. The forward primer was 5'-GAAACTATGTATCCGGCT-3' and the reverse primer was 5'-TGACTCACTCCATTCGGA-3'. The $25 \mu \mathrm{l}$ reaction mixtures contained $0.5 \mu \mathrm{l}(10 \mathrm{pmol} / \mu \mathrm{l})$ of each of the forward and reverse primer, $12.5 \mu 1$ of master mix, $1 \mu 1$ of template DNA and $10.5 \mu 1$ of nuclease free water. The reactions were performed in a PCR Thermal Cycler S1000 ${ }^{\mathrm{TM}}$ (Bio-Rad, USA). Amplification was conducted by a temperature cycling protocol consisting of initial denaturation at $95^{\circ} \mathrm{C}$ for $5 \mathrm{~min}, 30$ cycles of $30 \mathrm{~s}$ for denaturation at $95^{\circ} \mathrm{C}, 1 \mathrm{~min}$ of primer annealing at $45^{\circ} \mathrm{C}$, and $1 \mathrm{~min}$ of extension at $72^{\circ} \mathrm{C}$, followed by 5 min of final extension at $72^{\circ} \mathrm{C}$. Following RT-PCR, $7 \mathrm{ml}$ of the amplicons were electrophoresed in a $1 \%$ Tris acetateEDTA agarose gel and electrophoresis was carried out at 80 volts for 60 minutes. The gel was stained with ethidium bromide and the bands were visualized at $312 \mathrm{~nm}$ using a gel documentation system (DNA Bio-Rad imaging system). Product sizes were determined with reference to a 100bp DNA ladder.

\section{RESULTS AND DISCUSSION}

\section{Clinical signs}

The most frequently observed clinical signs were respiratory distress characterized by pneumonia, coughing, laboured breathing and ocular and nasal discharge. Initially, nasal and ocular discharge was watery in nature, which later becomes mucopurulent leading to attachment of both the eyelids. This reports correlate with the findings of Mortella et al. (2006) and Zhao et al. (2015). High rise of body temperature from $102.8-105^{\circ} \mathrm{F}$, anorexia, lethargy, dehydration and weight loss were noticed in all the animals at the initial phase of the disease. Similar findings were reported by Elia et al. (2015). Biphasic fever was recorded as a prominent clinical signs in almost all the affected animals. The initial rise of temperature was seen at the viraemic stage when virus was circulating in the blood, following rise of temperature was reported due to the secondary bacterial infections as CDV results 

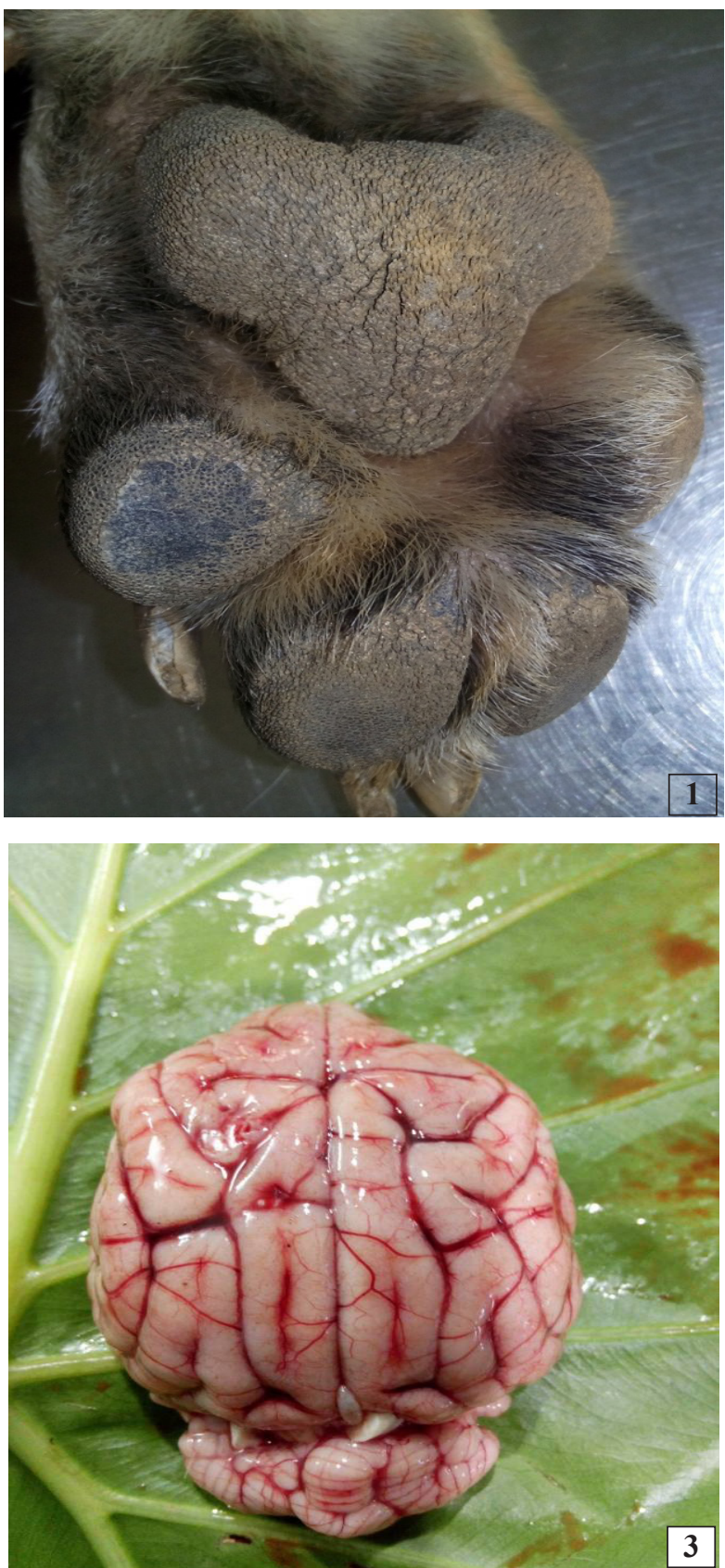
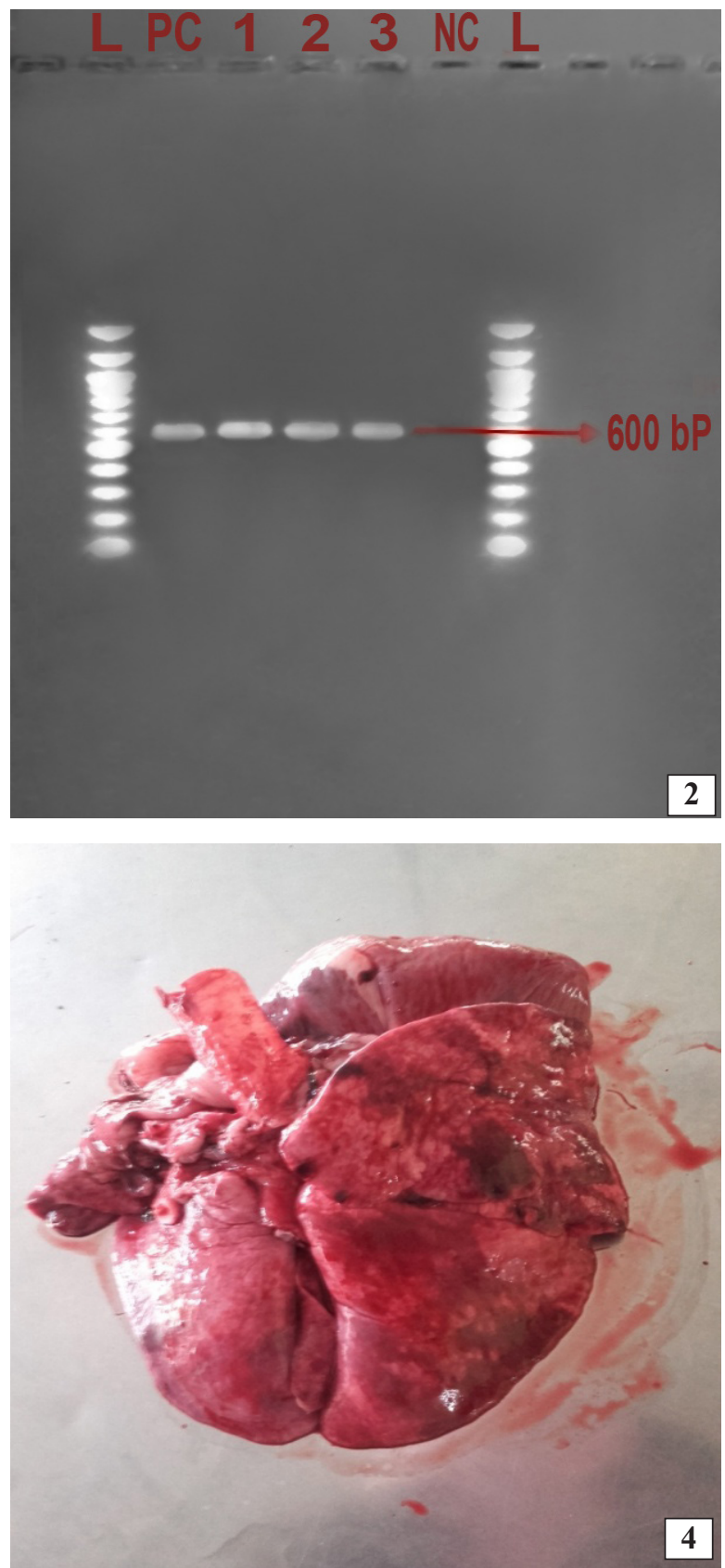

Figs. 1-4: Photographs showing (1) Hyperkeratosis of the digital pads, (2) RT-PCR amplification of the NP gene (L= Standard 100bp DNA ladder, $\mathrm{PC}=$ Positive control, 1,2,3 = Positive samples, $\mathrm{NC}=$ Negative control), (3) Congestion in the brain, (4) Patchy areas of emphysema, congestion and haemorrhages in the lungs indicating bronchopneumonia

immunosupression by affecting lymphoid organs. In young animals, pustular dermatitis was noticed in the ventral abdominal wall, inner side of the thigh and ears. Both hyperkeratosis and parakeratosis of the skin around the eyes and nose were observed in some of the dogs more than two years of age. Foot pads were hard to touch and painful due to hyperkeratosis (Fig. 1) which supports the findings of Carvallo et al. (2012). In some animals, neurological disorders were evident, which includes salivation, partial to generalized seizure, paddling movements and tremor. 
Few chronic cases were reported with posterior paralysis. Neurological signs appear as CDV may affect the grey and white matter of the central nervous system (Amude et al., 2007).

\section{Reverse transcriptase-polymerase chain reaction (RT- PCR)}

RT-PCR was used as a diagnostic tool for the detection of CDV in the present study. Amplification of NP gene was found in 41.67 percent $(n=25)$ cases out of total 60 sample tested. The positive samples and control showed clear band at $600 \mathrm{bp}$ against absence of band in negative control (Fig. 2). Since the NP gene is required for replication of the virus, the mRNA of the NP gene is transcribed more extensively in the infected cells (Shin et al., 1995) and appears to be a good marker of infection (Alcalde et al., 2013; Yi and Cheng 2014).

\section{Gross pathology}

Necropsy was performed in six animals found positive in RT-PCR. The brain lesions observed were haemorrhages, congestions and meningitis (Fig. 3). Similar findings were also reported by Machida et al. (1993). The virus has the affinity towards central nervous system (Jones and Hunts, 2006) that could be the cause of gross alteration in the CNS. Lungs of the affected animals showed congestion, focal emphysema, dark patchy pneumonic areas in all the lobes especially in the diaphragmatic lobes indicate bronchopneumonia (Fig. 4). The affected lungs were dark in colour and heavy. Squeezing of the cut section of the lungs revealed frothy exudates coming out particularly from the bronchi and bronchioles. The tracheal lumen also contains mucopurulent exudets and the mocosa was congested. These findings correlate with the reports of earlier workers (Lan et al., 2006; Kubo et al., 2007). From the previous literature it was revealed that lung was the target organ for CDV and initial replication of the virus take place in the macrophages of the lungs (Beineke et al., 2009). The stomach was found to be empty with some watery contents in all the 6 positive cases. Haemorrhages were observed across the mucosal folds in the fundic and pyloric junction of the stomach. The intestinal mucosa showed congestion and haemorrhages with thickening of the intestinal wall in some cases. Similar findings were recorded by Galan et al. (2014) and Zhao et al. (2015).
The kidneys were congested and haemorrhagic with presence of necrotic foci over the cortex. This finding is correlates with Jones and Hunts (2006). The urinary bladder was found distended and on opening blood tinged urine was came out. The mucosal surface of the bladder revealed petecheal to diffuse ecchymotic haemorrhages spread over the whole mucous membrane. Congestion with mild to moderate enlargement of the lymphoid organs including spleen was noticed. The lesions were marked in the mesenteric lymph nodes. This gross alteration may be due to the affinity of the CDV to the lymphoid organs (Kumagai et al., 2003).

\section{Histopathology}

Non-supurative encephalomyelitis was the most prominent microscopic change in the brain. Other changes in the brain were multifocal areas of demyelination in the cerebrum and cerebellum (Fig. 5). Oligodendrocytes were metabolically active cell in the central nervous system and play an important role for myelin renewal and when brain tissues were infected by CDV, degeneration of oligodendrocyte was often occurred because of metabolic impairment which may be the cause of demyelination (Yao-qian et al., 2013). Most of the neurons were degenerated and marked perivascular cuffing predominantly with lymphocytes and plasma cells. Degeneration of the Purkinje cells seen in few cases of this study was also reported by Lisiak et al. (1979). Several eosinophilic intranuclear and intracytoplasmic inclusion bodies were observed in the neuron and glial cells (Fig. 6) which are characteristic histopathological changes recorded by various workers (Lan et al., 2006; Kubo et al., 2007; Renteria-Solis et al., 2014). Alveolar septa showed marked thickening due to presence of oedematous exudates, haemorrhage and infiltrating cells indicative of interstitial pneumonia (Fig. 7). The alveolar lumen was occluded with serofibrinous exudates, polymorphonuclear cells and mononuclear cells with hyperplasia of the alveolar lining epithelium. Sqoumous metaplasis of bronchiolar epithelia were occasionally seen in the lungs. These findings are in accordance with Apple et al. (1994). Inclusion bodies, both intranuclear and intracytoplasmic type were also observed in the alveolar macrophages, epithelial cells of the bronchioles, kidney, stomach and urinary bladder (Fig. 8,9,10,11), which were considered as a characteristic histopathological lesions in CD cases (Lan et al., 2006; Zhao et al., 2015; Green and 

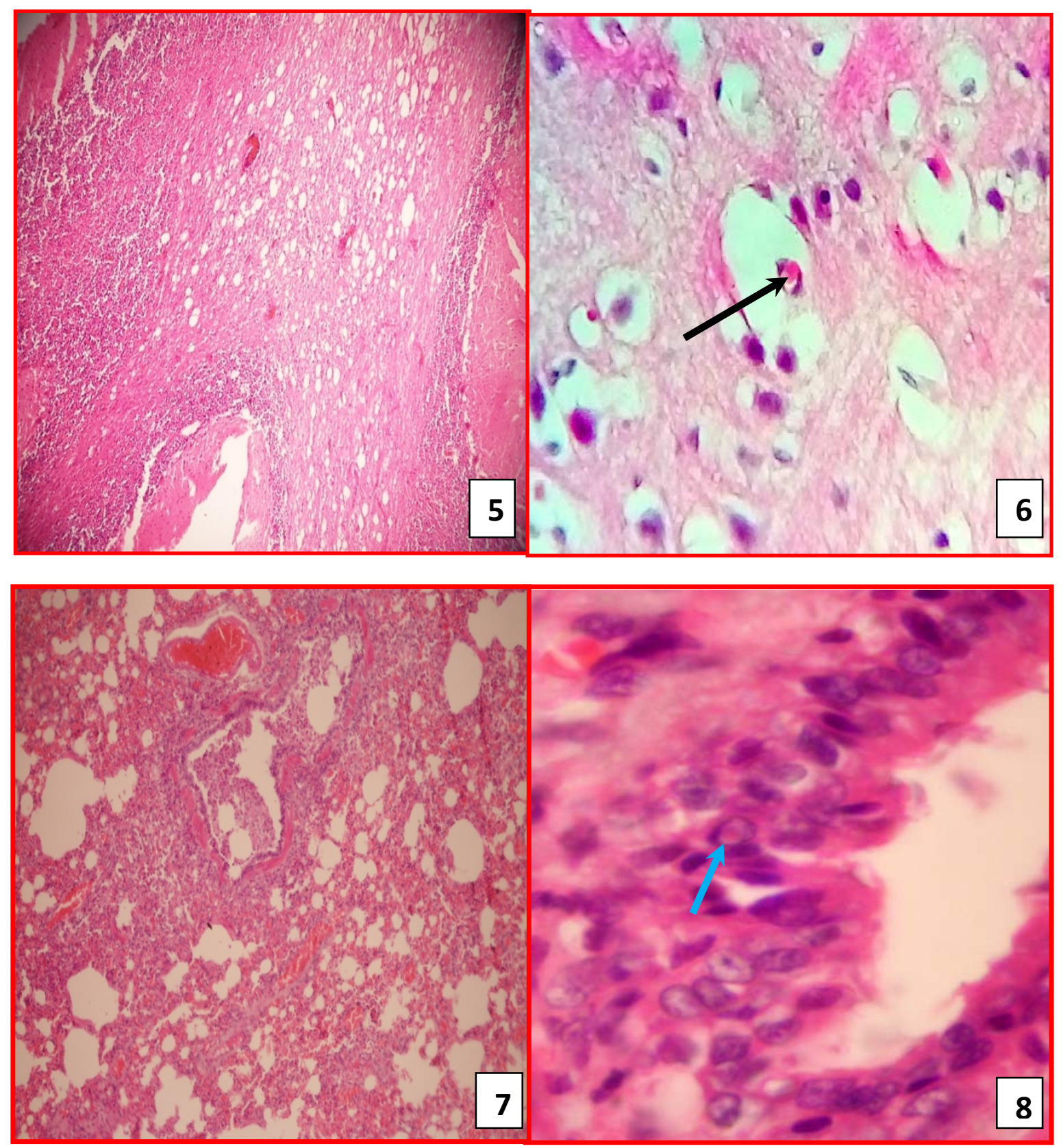

Figs. 5-8: Photomicrograph showing. (5) Empty spaces in the cerebellum indicating demyelination (H.\&E.x100), (6) Intranuclear inclusion in the microglial cells (arrow) of the cerebrum (H.\&E.x1000), (7) Congestion, haemorrhages, emphysema, bronchopneumonia with exudates in the bronchiolar lumen (H.\&E.x400), (8) Bronchiolar hyperplasia with intranuclear inclusion (arrow) in the bronchiolar epithelial cells (H.\&E.x1000)

Vandevelde, 2011; Kubo et al., 2007). This is in agreement with the present findings where inclusion bodies could be demonstrated in all the carcasses. The inclusion bodies recorded in both the cells were found to be round with intense eosinophilic appearance. The stomach revealed congestion, haemorrhage, degeneration and desquamation of lining epithelial cells which is also recorded by Galan et al. (2014). The stomach showed few necrotic cells with eosinophilic intranuclear inclusion bodies in the epithelial cells of intestinal crypts and gastric glands (Kubo et al., 

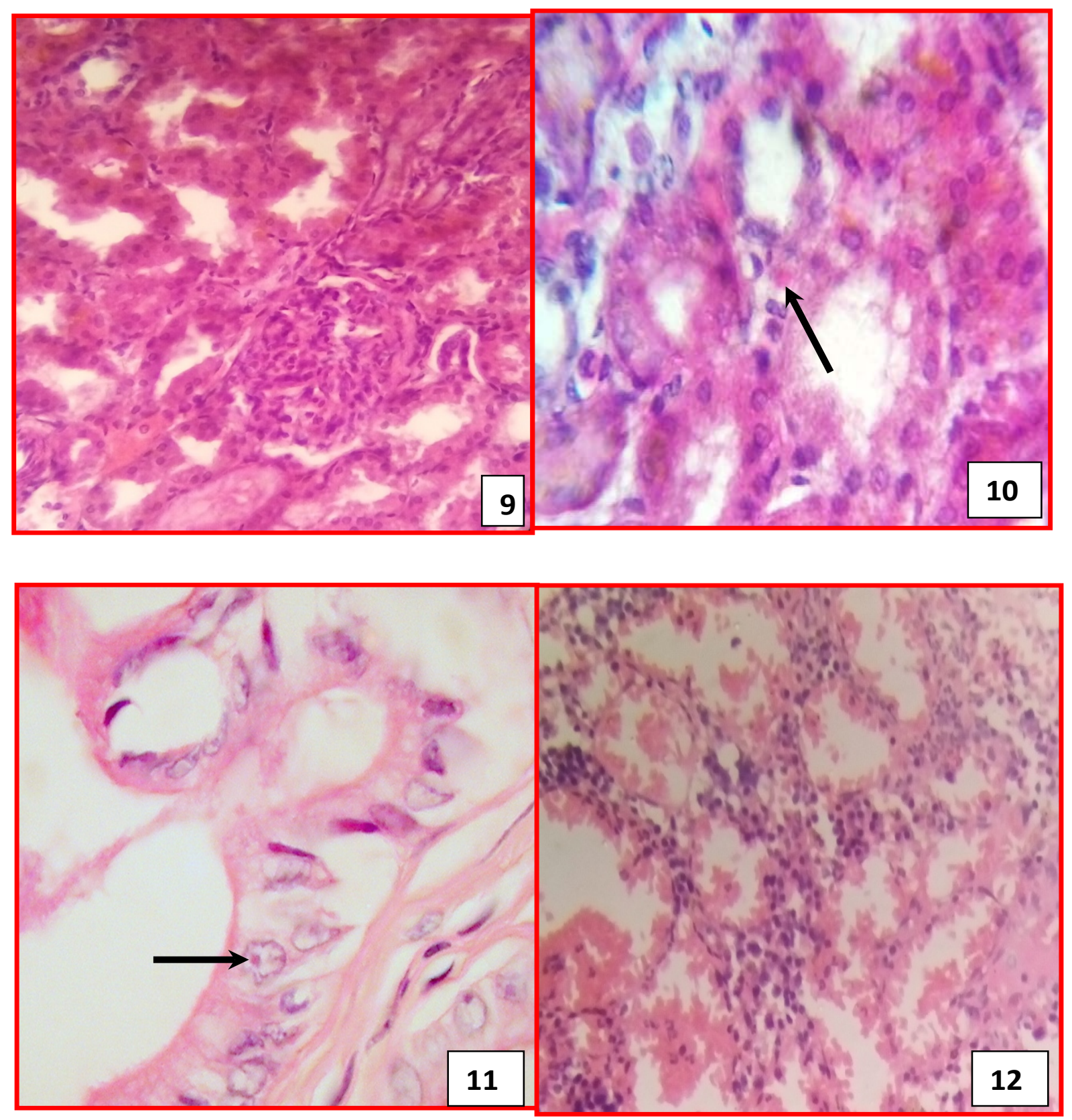

Figs. 9-12: Photomicrograph showing. (9) Tubular degeneration, haemorrhage and increase hypercellularity of the glomerulus (H.\&E. $\mathrm{x} 400$ ), (10) Presence of intracytoplasmic inclusion body (arrow) in the tubular epithelium of kidney (H.\&E.x1000), (11) Intranuclear acidophilic inclusion body (arrow) in the mucosal epithelium of the stomach (H.\&E.x1000), (12) Haemorrhages with marked lymphoid depletion in the lymphoid follicles of lymph node (H.\&E.x400).

2007). The CD virus is pantropic and has special affinity to the epithelial cells of the body where virus replicates, might damage to the stomach mucosa (Jones and Hunts, 2006). Intestine revealed necrosis and detachment of the villus epithelium and infiltration of mononuclear cells in the lamina propia. Similar findings reported by Zhao et al. (2015). The epitheliotropic nature of the virus might be the reason of histopathological alterations found in the present study (Green and Vandevelde, 2011). Degeneration, necrosis and sloughing of transitional epithelium with 
congestion and haemorrhages in the submucosal layer were noticed. Mild infiltration with mononuclear infiltrating cells was observed in the sub mucosa and muscularis layer. These findings correlate with Zhao et al. (2015). Spleen and lymph nodes revealed congestion and haemorrhages with mild to moderate depletion of lymphocytes (Fig. 12) in the splenic white pulp and in the follicles as well as. The canine distemper virus has affinity towards the lymphoid organs and replicates in the lymphoid cells, so, it could be the cause of lymphoid depletion (Lan et al., 2006).

\section{CONCLUSION}

The CDV NP gene was detected in the whole blood samples of infected animals with the help of RT-PCR which can be considered as a sensitive, reliable and fast method for early diagnosis of CDV infection. Most common clinical signs manifested by the animals were biphasic fever, oculo-nasal discharge, hyperkeratosis, gastroenteritis and nervous disorders. The gross lesions and histopathological demonstration of inclusion bodies in the different tissues recorded in this study were correlates with the clinical signs manifested by the animals found positive in RT-PCR.

\section{ACKNOWLEDGEMENTS}

The research work was funded by Department of Animal biotechnology, A.A.U., College of Veterinary Science, Khanapara, Guwahati, Assam. State Biotech Hub fund is highly acknowledged for providing scholarship to carry out the research work.

\section{REFERENCES}

Alcalde, R., Kogika, M.M., Fortunato, V.B., Coelho, B.M., Lopes, L.R., Paiva, P.B. and Durigon, E.L. 2013. Canine distemper virus: detection of viral RNA by Nested RT-PCR in dogs with clinical diagnosis. Braz. J. Vet. Anim. Sci., 50(1): 74-76.

Amude, A.M., Alfieri, A.A. and Alfeiri, A.F. 2007. Clinico-pathological findings in dogs with distemper encephalomyelitis presented without characteristic signs of the disease. Res. Vet. Sci., 82: 416-422.

Apple, M.J.G., Yates, R.A., Foley, G.L., Bernstein, J.J., Santinelli, S., Spelman, L.H., Miller, L.D., Arp, L.H., Anderson, M., Barr, M., Pearce-Kelling, S. and Summer, B.A. 1994. Canine distemper epizootic in lions, tigers, and leopards in North America. J. Vet. Diagn. Invest., 6: 277-288.
Beineke, A., Baumgärtner, W. and Wohlsein, P. 2015. Cross species transmission of canine distemper virus -an update. One Health, 1: 49-59.

Beineke, A., Puff, C., Seehusen, F. and Baumgartner, W. 2009. Pathogenesis and immuno-pathology of systemic and nervous canine distemper. Vet. Immunol. Immunopathol., 127: 1-18.

Carvalho, O.V., Botelho, C.V., Ferreira, C.G.T., Scherer, P.O., Soares-Martins, J.A.P., Almeida, M.R. and Junior, A.S. 2012. Immunopathogenic and neurological mechanism of canine distemper virus. Adv. Virolo., 2: 163860.

Culling, C.F.A. 1974. Handbook of Histopatholological and Histochemical Techniques. $3^{\text {rd }}$ edn. Butterworth and Co (Publishers) Ltd., pp. 402-403.

Dongre, J., Mehta, H.K. and Maheswari, P. 2013. Incidences of canine distemper infection in an around Mhow region of Madhya Pradesh. Int. J. Agri. Sc. Vet. Med., 1(4): 69-71.

Elia, G., Camero, M., Losurdo, M., Lucente, M.S., Larocca, V., Martella,V., Decaro, N. and Buonavoglia, C. 2015. Virological and serological findings in dogs with naturally occurring distemper. J. Virol. Methods, 213: 127-130.

Galan, A. Gamito, A. Carletti, B.E. Guisado, A. Mulas, J.M., Perez, J. and Martin, E.M. 2014. Uncommon acute neurological presentation of canine distemper in 4 adult dogs. Can. Vet. J., 55: 373-378.

Greene, C.E. and Vandevelde, M. 2011. Infectious Diseases of the Dog and Cat. $4^{\text {th }}$ Edn., Elsevier Publication.

Jones, T.C.; Hunt, R.D. and King, N.W. 2006. Veterinary Pathology. $6^{\text {th }}$ Edn., Blackwell Publishing, Oxford, U.K.

Kim, D., Jeoung, S.Y., Ahn, S.J., Lee, J.H., Pak, S.I. and Kwon, H.M. 2006. Comparison of tissue and fluid samples for the early detection of canine distemper virus in experimentally infected dogs. J. Vet. Med. Sci., 68(8): 877-879.

Kubo, T., Kagawa, Y., Taniyama, H. and Hasegawa, A. 2007. Distribution of inclusion bodies in tissues from $100 \mathrm{dogs}$ infected with canine distemper virus. J. Vet. Med. Sci., 69(5): 527-529.

Kumagai, K., Yamaguchi, R., Uchida, K. and Tateyama, S. 2003. Lymphoid apoptosis in acute canine distemper. J. Vet. Med. Sci., 66(2): 175-181.

Lan, N.T., Yamaguchi, R., Inomata, A., Furuya, Y., Uchida, K., Sugano, S. and Tateyama, S. 2006. Comparative analysis of canine distemper viral isolates from clinical cases of canine distemper in vaccinated dogs. Vet. Microbiol., 115: 32-42.

Lisiak, J.A. and Vandevelde, M. 1979. Polioencephalomalacia associated with canine distemper virus infection. Vet. Pathol., 16: $650-660$

Machida, N., Kiryu, K., Oh-ishi, K., Kanda, E., Izumusawa, N. and Nakamura, T. 1993. Pathology and epidemiology of 
canine distemper in raccoon dogs (Nyctereutes procyonoides). J. Comp. Pathol., 108(4): 383-392.

Martella, V., Cirone, F., Elia, G., Lorusso, E., Decaro, N., Campolo, M., Desario, C., Lucente, M.S., Bellacicco, A.L., Blixenkrone-Moller, M., Carmichael, L.E. and Buonavoglia, C. 2006. Heterogeneity within the hemagglutinin genes of canine distemper virus (CDV) strains detected in Italy. Vet. Microbiol., 116: 301-309.

Renteria-Solis, Z., Forster, C., Aue, A., Wittstatt, U., Wibbelt, G. and Konig, M. 2014. Canine distemper outbreak in raccons suggest pathogen interspecies transmission amond alien and native carnivores in urban area from Germany. Vet. Microbiol., 174: 50-59.

Saito, T.B., Alfieri. A.A., Wosiacki, S.R., Negrao, F.J., Morais, H.S.A. and Alfieri, A.F. 2006 Detection of canine distemper virus by reverse transcriptase-polymerase chain reaction in the urine of dogs with clinical signs of distemper encephalitis. Res. Vet. Sci., 80: 116-119.
Shin, Y., Mori, T., Okita, M., Gemma, T., Kai, C. and Mikami, T. 1995. Detection of canine distemper virus Nucleocapsid protein gene in canine peripheral blood mononuclear cells by RT-PCR. J. Vet. Med. Sci., 57(3): 439-445.

Yao-qian, P., Xoing-you, L., Li-ping, M., Guang-rui, Z., Yinke, X., Jin-shan, C. and Takashi, Y. 2013. Pathogenesis of demyelinating encephalopathy in dogs with spontaneous acute canine distemper. J. Integrative Agri., 12(2): 334-343.

Yi, L. and Cheng, S. 2014. A monoclonal antibody against truncated N protein (aa 277-471) of canine distemper virus. Monoclonal Antibodies in Immunodiagnosis and Immunotherapy, 33(1): 52-56.

Zhao, J., Shi, N., Sun, Y., Martella, V., Nikolin, V., Zhu, C., Zhang, H., Hu, B., Bai, X. and Yan, X. 2015. Pathogenesis of canine distemper virus in experimentally infected raccoon dogs, foxes, and minks. Antiviral Res., 122: 1-11. 